\title{
Hyponatraemia as a marker for high renin heart failure
}

\author{
T BARRY LEVINE, JOSEPH A FRANCIOSA, THOMAS VROBEL, JAY N COHN \\ From the Department of Medicine, University of Minnesota Medical School, Minneapolis, Minnesota, USA
}

SUMMARY The factors that might activate the renin-angiotensin system in treated heart failure were explored. Serum $\mathrm{Na}^{+}$correlated inversely with plasma renin activity. The degree of congestive heart failure measured by right atrial pressure, pulmonary capillary wedge pressure, cardiac index, and systemic vascular resistance did not correlate with plasma renin activity. Similarly, renal function as measured by blood urea nitrogen, creatinine, and urinary $\mathrm{Na}^{+}$excretion did not correlate with plasma renin activity. In a prospectively screened group, seven patients with congestive heart failure who were found to be hyponatraemic had plasma renin activities greater than $15 \mathrm{ng} / \mathrm{ml}$ per $\mathrm{h}$. Serial determinations in one patient showed plasma renin activity to vary inversely with the serum $\mathrm{Na}^{+}$. It is concluded that serum sodium can be used to identify those patients with congestive heart failure who have a high plasma renin activity. The value of identifying these high renin heart failure patients was seen in their response in four cases to specific therapy with a converting enzyme inhibitor.

The renin-angiotensin system may play an important homeostatic role in both experimental and clinical congestive heart failure. ${ }^{1-4}$ Increased circulating angiotensin II could contribute to systemic vasoconstriction which supports blood pressure ${ }^{56}$ but also might adversely affect left ventricular performance. ${ }^{7}$. Plasma renin activity has been reported to vary widely in patients with heart failure 289 but the mechanism of its stimulation and the reason it is raised in some patients but not in others is not understood.

Haemodynamics, renal function, or volume factors all might be expected to be capable of stimulating the renin-angiotensin system. ${ }^{810^{-14}}$ Since recent reports have shown a beneficial haemodynamic response in patients with heart failure to agents that block the activity of the renin angiotensin system, 21516 an understanding of the factors that stimulate it in heart failure and the recognition of clinical correlates of high plasma renin activity might have important therapeutic implications.

In the present study we have explored the possible influence of haemodynamic and renal functional factors on plasma renin activity in a group of patients with moderate to severe heart failure, in hospital and carefully stabilised. The data confirm earlier work ${ }^{8}$ that there is a strong negative correlation of plasma renin activity with serum sodium and indicate that the former does not correlate with other measured variables. Furthermore, a low serum sodium appears to be a fairly reliable guide to high plasma renin activity in heart failure.

Accepted for publication 17 September 1981

\section{Subjects and methods}

Forty-two patients underwent an extensive haemodynamic and renal evaluation. The patients were studied in a stable state after being in hospital for three to five days on a 43 or $86 \mathrm{mmol}$ sodium and 100 mmol potassium diet. Thirty-eight of the patients were taking digoxin and all were taking diuretics ( 37 patients frusemide alone, and five patients frusemide and spironolactone). All cardiac drugs except antiarrhythmic agents were withheld on the day of the study. Informed consent was obtained from each patient for the study procedure which had been approved by the University Committee on the Use of Human Subjects in Research.

On the morning of the study the patients fasted. In 36 patients a thermodilution Swan-Ganz flow-directed balloon tipped catheter was inserted percutaneously from a vein in the antecubital fossa and advanced to a position in the pulmonary artery where inflating the balloon occluded a pulmonary artery branch. The brachial artery was percutaneously cannulated with an Amplatz 0.038 arterial catheter. Pressures were monitored with Bell and Howell 4-3271 transducers. Electrocardiographic monitoring was continuous throughout the study. Pressure and electrocardiogram were recorded on a Hewlett Packard multichannel direct writing recorder. Mean pressures were electronically integrated. Right atrial pressure, pulmonary artery pressure, pulmonary capillary wedge pressure, and brachial artery pressure in $\mathrm{mmHg}$, and thermodilution cardiac outputs in $1 / \mathrm{min}$ were 
obtained. In the other six patients a venous line was passed from a vein in the antecubital fossa to obtain central venous pressure. Brachial artery pressure was measured by cuff sphygmomanometry and cardiac outputs were determined by the $\mathrm{CO}_{2}$ rebreathing method using a Beckman LB2 gas analyser. ${ }^{17}$

After all catheters were positioned the subjects were allowed to rest for one hour. Haemodynamic measurements were then made and blood samples drawn for serum electrolytes, serum creatinine, and plasma renin activity by radioimmunoassay using a Renak assay (Roche) as described by Sealey et al. ${ }^{18}$ The day before the study a 24-hour urine sample was collected for determination of sodium and creatinine excretion.

Systemic vascular resistance was calculated using the formula:

$$
\operatorname{SVR}\left(\text { dyne } \mathrm{s} \mathrm{cm}^{-5}\right)=\frac{\mathrm{AP}-\mathrm{RA}}{\mathrm{CO}} \times 80,
$$

where SVR is systemic vascular resistance, AP is brachial artery pressure, RA is right atrial pressure, and $\mathrm{CO}$ is cardiac output. Pulmonary vascular resistance was calculated using the formula:

$$
\text { PVR (dyne s cm-5) }=\frac{\mathrm{PA}}{\mathrm{CO}} \times 80,
$$

where PVR is pulmonary vascular resistance, and PA is pulmonary artery pressure.

These data were analysed using variable linear regression and Student's t test.

\section{Results}

Resting haemodynamic, renal functional, and electrolyte data for the $\mathbf{4 2}$ patients studied are presented in Table 1. The low cardiac index and high right atrial and pulmonary capillary wedge pressures reflect the severity of the heart failure. Renal function was modestly diminished as evidenced by the slightly increased blood urea nitrogen and creatinine.

The plasma renin activity ranged from $0.3 \mathrm{ng} / \mathrm{ml}$ per $\mathrm{h}$ to $85.2 \mathrm{ng} / \mathrm{ml}$ per $\mathrm{h}$ (Fig. 1). The normal plasma renin activity in our laboratory ranges from 0 to 8.0 $\mathrm{ng} / \mathrm{ml}$ per $\mathrm{h}$. When the level of plasma renin activity was compared with the various aspects of haemodynamics, renal function, or electrolyte status, a strong $(p<0.001)$ inverse correlation $(r=-0.65)$ between plasma renin activity and serum $\mathrm{Na}^{+}$was found. No significant correlation was found between plasma renin activity and cardiac index, mean arterial pressure, pulmonary capillary wedge pressure, systemic vascular resistance, pulmonary vascular resistance, serum $\mathrm{K}^{+}$, serum creatinine, or blood urea nitrogen (Table 1).

The patients were divided arbitrarily into a low renin group ( 0 to $16 \mathrm{ng} / \mathrm{ml}$ per $\mathrm{h}$ ) and a high renin group $(>16 \mathrm{ng} / \mathrm{ml}$ per $\mathrm{h})$. There were 31 patients in the low renin group and 11 in the high renin group (Table 2). Serum $\mathrm{Na}^{+}$for the low renin group

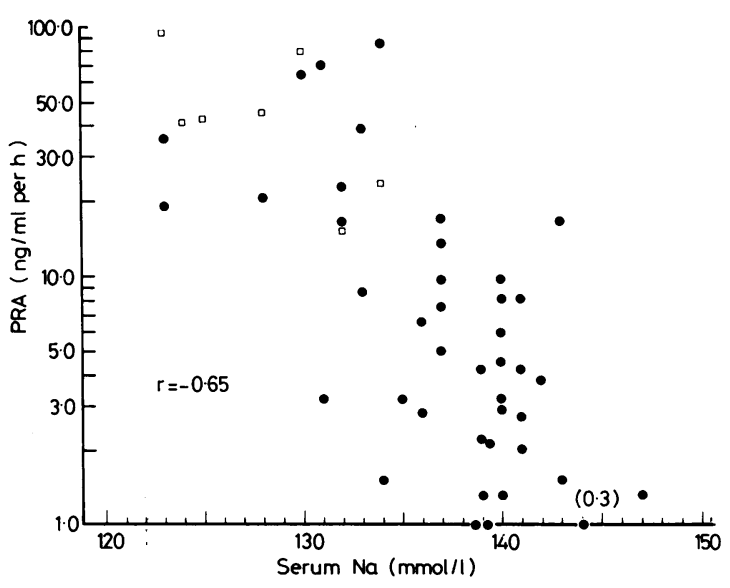

Fig. 1 Correlation between plasma renin activity $(P R A)$ and serum $\mathrm{Na}$ in patients with congestive heart failure. The closed dots represent the 42 patients studied. The open squares represent the seven patients prospectively marked as having high plasma renin activity because they were at the time hyponatraemic.

\begin{tabular}{|c|c|c|c|c|}
\hline & No. & Mean & Correlation (r) & $p$ for correlation \\
\hline 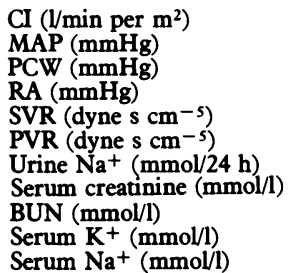 & $\begin{array}{l}42 \\
42 \\
35 \\
42 \\
41 \\
35 \\
27 \\
41 \\
40 \\
41 \\
49\end{array}$ & $\begin{aligned} 2.1 & \pm 0.1 \\
86.0 & \pm 2.0 \\
24.4 & \pm 1.2 \\
8.2 & \pm 0.9 \\
1821 & \pm 108 \\
766 & \pm 58 \\
51.1 & \pm 7.4 \\
114.9 & \pm 8.8 \\
9.99 & \pm 1.07 \\
4 \cdot 1 & \pm 0.1 \\
137 & \pm 1\end{aligned}$ & $\begin{array}{r}0.15 \\
-0.15 \\
0.13 \\
-0.03 \\
-0.07 \\
0.12 \\
-0.05 \\
-0.06 \\
0.08 \\
0.23 \\
-0.65\end{array}$ & $\begin{array}{l}\text { NS } \\
\text { NS } \\
\text { NS } \\
\text { NS } \\
\text { NS } \\
\text { NS } \\
\text { NS } \\
\text { NS } \\
\text { NS } \\
\text { NS } \\
0 \cdot 001\end{array}$ \\
\hline
\end{tabular}

Table 1 Haemodynamic and renal function in patients with heart failure and their correlation to plasma renin activity

CI, cardiac index; MAP, mean arterial pressure; PCW, pulmonary capillary wedge pressure; RA, right atrial pressure; SVR, systemic vascular resistance; PVR, pulmonary vascular resistance; BUN, blood urea nitrogen. 
Table 2 Haemodynamics and renal function in high renin heart failure vs low renin heart failure

\begin{tabular}{|c|c|c|c|}
\hline & $\begin{array}{l}\text { Low renin }(31) \\
(0-16 \mathrm{ng} / \mathrm{ml} \text { per } \mathrm{h})\end{array}$ & $\begin{array}{l}\text { High renin }(11) \\
(>16 \mathrm{ng} / \mathrm{ml} \text { per } \mathrm{h})\end{array}$ & $\begin{array}{l}\text { Probability } \\
\text { (low vs high) }\end{array}$ \\
\hline $\begin{array}{l}\text { CI }(1 / \text { min per m²) } \\
\text { MAP }(\mathrm{mmHg}) \\
\text { PCW }(\mathrm{mmHg}) \\
\text { RA (mmHg) } \\
\text { SVR (dyne s cm-5) } \\
\left.\text { PVR (dyne s } \mathrm{cm}^{-5}\right) \\
\text { Urine } \mathrm{Na}^{+}\left(\mathrm{mmol}^{-5} / \mathrm{h}\right) \\
\text { Serum creatinine }(\mathrm{mmol} / \mathrm{l}) \\
\text { BUN }(\mathrm{mmol} / \mathrm{l}) \\
\text { Serum } \mathrm{K}^{+}(\mathrm{mmol} / \mathrm{l}) \\
\text { Serum } \mathrm{Na}^{+}(\mathrm{mmol} / \mathrm{l})\end{array}$ & $\begin{aligned} 2.1 & \pm 0.1 \\
87.1 & \pm 2.1 \\
24.4 & \pm 1.2 \\
7.9 & \pm 1.1 \\
1876 & \pm 122 \\
747 & \pm 73 \\
49.5 & \pm 6.5 \\
114.9 & \pm 8.8 \\
9.28 \pm & 1.07 \\
4.1 & \pm 0.1 \\
139 \pm 1 & \pm 1\end{aligned}$ & $\begin{aligned} & 2 \cdot 2 \pm 0 \cdot 2 \\
& 83 \cdot 0 \pm 2 \cdot 9 \\
& 25 \cdot 0 \pm 1 \cdot 3 \\
& 9 \cdot 0 \pm 2 \cdot 1 \\
& 1675 \pm 233 \\
& 815 \pm \pm 9 \\
& 57 \cdot 8 \pm 30 \cdot 1 \\
& 1 \cdot 3 \pm 0 \cdot 1 \\
& 33 \pm \pm \\
& 4 \cdot 5 \pm \pm \cdot 1 \\
& 131 \pm \pm 2\end{aligned}$ & $\begin{array}{l}\text { NS } \\
\text { NS } \\
\text { NS } \\
\text { NS } \\
\text { NS } \\
\text { NS } \\
\text { NS } \\
\text { NS } \\
\text { NS } \\
0.05 \\
0.001\end{array}$ \\
\hline
\end{tabular}

averaged $139 \pm 1 \mathrm{mmol} / \mathrm{l}$ vs $131 \pm 2 \mathrm{mmol} / \mathrm{l}$ for the high renin group. This difference was highly significant $(\mathrm{p}<0.001)$. Serum $\mathrm{K}^{+}$was also found to be significantly different $(p<0.05)$ when the low renin group $(K=4 \cdot 1 \pm 0.1 \mathrm{mmol} / \mathrm{l})$ was compared with the high renin group $(K=4.5 \pm 0.1 \mathrm{mmol} / \mathrm{l})$. In all other respects the groups were comparable. The degree of heart failure as measured by cardiac index, right atrial pressure, pulmonary capillary wedge pressure, systemic vascular resistance, or pulmonary vascular resistance was the same for both the high renin and low renin groups. Renal function as assessed by serum creatinine, blood urea nitrogen, and urinary $\mathrm{Na}^{+}$ excretion was also similar for both groups.
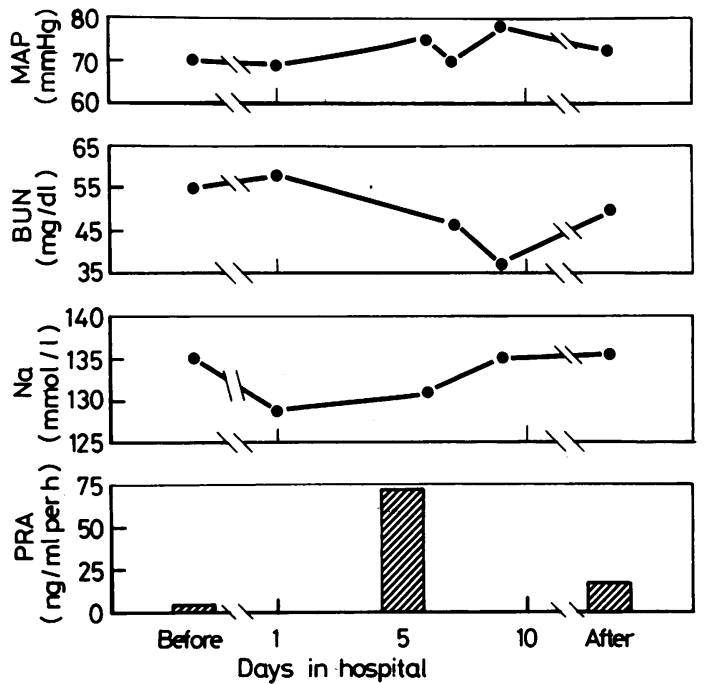

Fig. 2 Changes in plasma renin activity $(P R A)$, serum $N a$, blood urea nitrogen (BUN), and mean arterial pressure $(M A P)$ with time in a patient with congestive heart failure. Plasma renin activity rose conspicuously at a time when the patient was hyponatraemic. Renal function did not deteriorate during this period as the blood urea nitrogen tended to fall. The high renin state was not accompanied by a rise in arterial pressure. To convert BUNfigures to SI units, $1 \mathrm{mg} / \mathrm{dl} \approx 0.357 \mathrm{mmol} / \mathrm{l}$.
Since analysis of these data suggested that hyponatraemia might identify high renin patients, a prospective analysis was undertaken by screening all patients admitted to hospital at the University of Minnesota Hospital during a two-month period because of congestive heart failure. Seven of these screened patients were found to be hyponatraemic (serum $\mathrm{Na}^{+}$123-132 mmol/l). These patients were prospectively identified as having high renin heart failure. Subsequent plasma renin activity confirmed this in each patient: plasma renin activity ranged from 15.0 to $96.0 \mathrm{ng} / \mathrm{ml}$ per h (Fig. 1).

The dynamic relation between plasma renin activity and serum $\mathrm{Na}^{+}$was shown in one patient whose clinical course is shown in Fig. 2. This patient with severe congestive heart failure was admitted to hospital for a viral pneumonia. Before being admitted his serum $\mathrm{Na}^{+}$was normal and his plasma renin activity was low $(3.2 \mathrm{ng} / \mathrm{ml}$ per $\mathrm{h})$. During the acute illness he was found to be hyponatraemic. Plasma renin activity during that period was $71.2 \mathrm{ng} / \mathrm{ml}$ per $\mathrm{h}$. With recovery, serum $\mathrm{Na}^{+}$levels returned to normal and plasma renin activity fell to $(14.8 \mathrm{ng} / \mathrm{ml}$ per $\mathrm{h})$. Mean arterial pressure was unchanged during this period despite activation of the renin angiotensin system. The rise in plasma renin activity could not be accounted for on the basis of decreased renal function, since the blood urea nitrogen tended to fall during the high renin period.

\section{Discussion}

The inverse correlation between plasma renin activity and serum $\mathrm{Na}^{+}$noted in this series of patients with congestive heart failure proved diagnostically useful. As shown in Fig. 3, hyponatraemia appears to be a marker for high renin heart failure, since plasma renin activity in the hyponatraemic group (mean 38.5 \pm 6.6 $\mathrm{ng} / \mathrm{ml}$ per $\mathrm{h})$ was significantly higher $(\mathrm{p}<0.001)$ than plasma renin activity in those with normal serum sodium (mean $5 \cdot 1 \pm 0.8 \mathrm{ng} / \mathrm{ml}$ per $\mathrm{h}$ ). Furthermore, in our prospective analysis all seven patients identified 


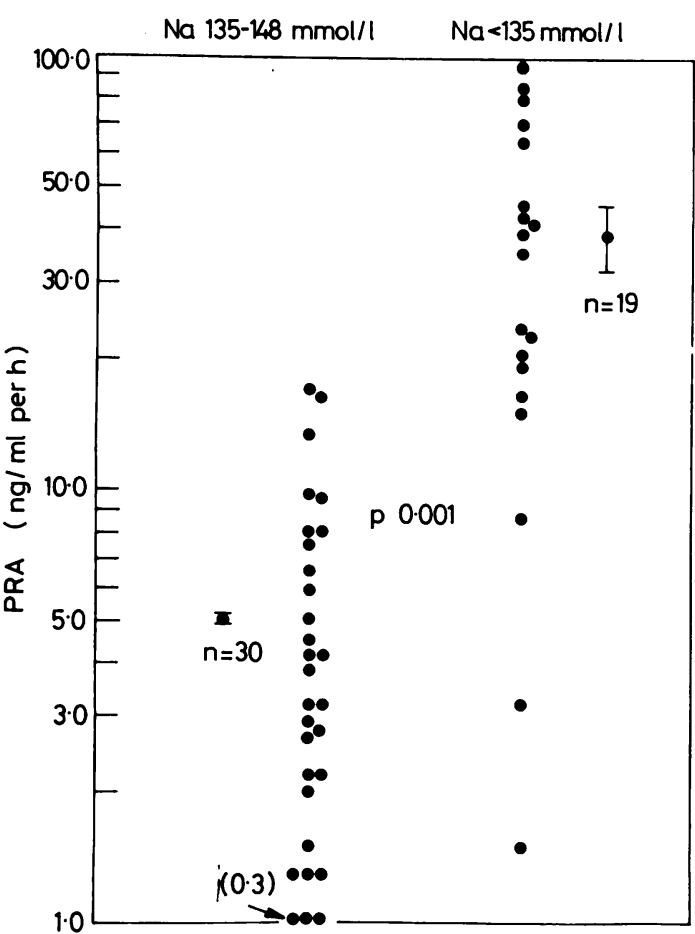

Fig. 3 Plasma renin activity $(P R A)$ in patients with normal serum sodium $(\mathrm{Na})$ and in hyponatraemic patients. Plasma renin activity was significantly higher in the hyponatraemic group.

with hyponatraemia had plasma renin activities greater than $15 \mathrm{ng} / \mathrm{ml}$ per $\mathrm{h}$.

An inverse correlation between plasma renin activity and serum $\mathrm{Na}^{+}$in heart failure has been known for some time. Brown and associates ${ }^{8}$ showed a very close inverse correlation in 17 untreated patients with heart failure. This strong inverse correlation was still present when 119 patients treated with diuretics and digitalis were analysed with the untreated patients. Hesse and co-workers ${ }^{19}$ showed a significant rise in plasma renin activity as serum sodium fell in 12 patients with heart failure. The present study confirms these observations. Furthermore, in these treated patients with moderate to severe congestive heart failure, neither severity of heart failure as measured by cardiac index, pulmonary capillary wedge pressure, or right atrial pressure nor degree of renal impairment as measured by blood urea nitrogen or creatinine played an important role in determining plasma renin activity.

A number of pathophysiological mechanisms could be responsible for this inverse correlation between plasma renin activity and serum $\mathrm{Na}^{+}$. Activation of the renin-angiotensin system results in increased levels of angiotensin II. The role of angiotensin II on renal absorption of $\mathrm{Na}^{+}$and water has been studied by a number of investigators, 82021 who have suggested an angiotensin-mediated reduction in renal medullary blood flow. The resultant increase in medullary osmolarity could result in excessive water reabsorption. Angiotensin II by stimulating arginine vasopressin production could also contribute to increased water reabsorption 2223 and hyponatraemia. We have recently shown raised arginine vasopressin levels in heart failure. ${ }^{24}$ Finally, angiotensin II has been shown experimentally to stimulate the thirst centre and result in polydypsia. ${ }^{25} 26$ The resultant hyponatraemia from any one or all of the above mechanisms could then directly stimulate renin secretion by a mechanism that is not entirely clear. ${ }^{27} 28$ It is of interest that an inverse correlation between plasma renin and plasma sodium has been reported in hypertension. ${ }^{29}$ Low serum sodium also is seen in the hyponatraemic hypertensive syndrome. ${ }^{30} \mathrm{It}$ is reasonable to assume that the same physiological mechanisms may be acting in the pathogenesis of hyponatraemia-hyper-reninaemia in all these situations.

Although plasma volume was not measured in these patients, the similar increases in right atrial pressure in the high and low renin groups and similar values for arterial pressure and cardiac output make it unlikely that differential stimulation of an intravascular volume receptor accounts for the high renin subgroup.

Although no correlation between plasma renin activity and serum $\mathrm{K}^{+}$was found, the potassium was significantly higher in the high renin than in the low renin group (Table 2 ). This trend is surprising, since high renin might be expected to induce secondary hyperaldosteronism ${ }^{31}$ and potassium infusion decreases renal renin secretion. ${ }^{32}{ }^{33}$ Furthermore, this difference in serum $\mathrm{K}^{+}$could not be accounted for by differing diuretic regimens. The values for serum $\mathrm{K}^{+}$ for both groups, however, were well within normal limits and the serum $\mathrm{K}^{+}$therefore was not useful in predicting the plasma renin activity.

The emergence of drugs that interfere with the renin-angiotensin system has made identifying those patients with high renin states potentially of clinical importance. Congestive heart failure has been treated with saralasin, a drug that competitively inhibits angiotensin $\mathrm{II}^{9}$ and with converting enzyme inhibitors that block the formation of angiotensin II. 215163435 The acute response to these drugs appears to be closely correlated with the baseline plasma renin activity. 23536 Table 3 shows the effectiveness of acute converting enzyme inhibition in four selected hyponatraemic patients with high renin heart failure. Mean arterial pressure and pulmonary capillary wedge pressure were significantly lowered and cardiac index significantly increased. Though preliminary 
Table 3 Response of patients with high renin heart failure to one dose of captopril, an angiotensin converting enzyme inhibitor

\begin{tabular}{|c|c|c|c|c|c|c|c|}
\hline Case No. & & $\mathrm{Na}^{+}(\mathrm{mmol} / \mathrm{l})$ & $P R A(n g / m l$ per $h)$ & $M A P(m m H g)$ & $P C W(m m H g)$ & $C I\left(l / m i n\right.$ per $\left.m^{2}\right)$ & SVR (dyne s $\mathrm{cm}^{-5}$ ) \\
\hline $\begin{array}{ll}1 & \mathrm{~B} \\
& \mathrm{C} \\
2 & \mathrm{~B} \\
& \mathrm{C} \\
3 & \mathrm{~B} \\
& \mathrm{C} \\
4 & \mathrm{~B} \\
& \mathrm{C} \\
\text { Mean } \pm \text { SD }\end{array}$ & $\begin{array}{l}\text { B } \\
\text { C }\end{array}$ & 132 & $\begin{array}{l}70.0 \\
63.8 \\
22.8\end{array}$ & $\begin{array}{l}75 \\
50 \\
100 \\
45 \\
92 \\
60 \\
78 \\
56 \\
86 \pm 5 \\
53 \pm 3^{\star}\end{array}$ & $\begin{array}{c}26 \\
8 \\
38 \\
9 \\
22 \\
9 \\
25 \\
8 \\
27 \cdot 8 \pm 3 \cdot 2 \\
8 \cdot 5 \pm 0 \cdot 31^{\star}\end{array}$ & $\begin{array}{l}2 \cdot 2 \\
2.6 \\
1.6 \\
2.4 \\
1.2 \\
1.6 \\
3.2 \\
3.5 \\
2 \cdot 1 \pm 0.4 \\
2.5 \pm 0.3^{\star}\end{array}$ & $\begin{array}{l}1455 \\
836 \\
3409 \\
1166 \\
3163 \\
1640 \\
888 \\
556 \\
2229 \pm 557 \\
1050 \pm 208\end{array}$ \\
\hline
\end{tabular}

B, baseline; C, after captopril.

${ }^{\star} \mathbf{p}<0.05$.

reports suggest that converting enzyme inhibitors may have beneficial long-term effects even in low renin heart failure, ${ }^{36}$ their mechanism of action in this setting is not entirely understood. Identification of high renin heart failure might be useful in selecting appropriate acute therapy. The present data suggest that a low serum sodium is a simple indicator of such cases and might identify patients who will acutely benefit most from therapy to inhibit the reninangiotensin system.

\section{References}

1 Watkins L Jr, Burton JA, Haber E, Cant JR, Smith FW, Barger AC. The renin-angiotensin-aldosterone system in congestive failure in conscious dogs. $\mathcal{f}$ Clin Invest 1976; 57: 1606-17.

2 Curtiss C, Cohn JN, Vrobel T, Franciosa JA. Role of the renin-angiotensin system in the systemic vasoconstriction of chronic congestive heart failure. Circulation 1978; 58: 763-70.

3 Genest J, Granger P, de Champlain J, Boucher R. Endocrine factors in congestive heart failure. Am $\mathcal{F}$ Cardiol 1968; 22: 35-42.

4 Davis JO. The physiology of congestive heart failue. In: Hamilton WF, Dow P, eds. Handbook of physiology. Circulation III. Washington, DC: American Physiological Society, 1965: 2071-122.

5 Haddy FJ, Molnar JI, Borden CW, Texter EC Jr. Comparison of direct effects of angiotensin and other vasoactive agents on small and large blood vessels in several vascular beds. Circulation 1962; 25: 239-46.

6 Sancho J, Re R, Burton J, Barger AC, Haber E. The role of the renin-angiotensin-aldosterone system in cardiovascular homeostasis in normal human subjects. Circulation 1976; 53: 400-5.

7 Cohn JN. Blood pressure and cardiac performance. $A m \mathcal{F}$ Med 1973; 55: 351-61.

8 Brown JJ, Davies DL, Johnson VW, Lever AF, Robertson JIS. Renin relationships in congestive cardiac failure, treated and untreated. Am Heart $\mathcal{F}$ 1970; 80: 329-42.

9 Turini GA, Brunner HR, Ferguson RK, Rivier JL, Gavras $H$. Congestive heart failure in normotensive man haemodynamics, renin, and angiotensin II blockade. $\mathrm{Br}$ Heart f 1978; 40: $1134-42$.

10 Davis JO, Freeman RH. Mechanisms regulating renin release. Physiol Rev 1976; 56: 1-56.

- 11 Skinner SL, McCubbin JW, Page IH. Control of renin secretion. Circ Res 1964; 15: 64-76.

12 Blaine EH, Davis JO, Witty RT. Renin release after hemorrhage and after suprarenal aortic constriction in dogs without sodium delivery to the macula densa. Circ Res 1970; 27: 1081-9.

13 Newsome HH, Bartter FC. Plasma renin activity in relation to serum sodium concentrations and body fluid balance. F Clin Endocrinol 1968; 28: 1704-11.

14 Gordon RD, Pawsey CGK. Relative effects of serum sodium concentration and the state of body fluid balance on renin secretion. $f$ Clin Endocrinol Metab 1971; 32: 117-9.

15 Davis R, Ribner HS, Keung E, Sonnenblick EH, LeJemtel TH. Treatment of chronic congestive heart failure with captopril, an oral inhibitor of angiotensinconverting enzyme. $N$ Engl F Med 1979; 301: 117-21.

16 Turini GA, Brunner HR, Gribic M, Waeber B, Gavras $H$. Improvement of chronic congestive heart-failure by oral captopril. Lancet 1979; i: 1213-5.

17 Franciosa JA, Ragan DO, Rubenstone SJ. Validation of the $\mathrm{CO}_{2}$ rebreathing method for measuring cardiac output in patients with hypertension or heart failure. $\mathcal{F} \mathrm{Lab}$ Clin Med 1976; 88: 672-82.

18 Sealey JE, Gerten-Banes J, Laragh JH. The renin system: variations in man measured by radioimmunoassay or bioassay. Kidney Int 1972; 1: 240-53.

19 Hesse B, Nielsen I, Bollerup AC, Olesen KH, Uhrenholdt A. Hemodynamics, compartments and the renin-aldosterone system in chronic heart failure. Eur $\mathcal{F}$ Cardiol 1975; 3: 107-15.

20 Black DAK. Renal rete mirabile. Lancet 1965; ii: 114152.

21 Brown JJ, Davies DL, Lever AF, Robertson JIS. Renin and angiotensin: a survey of some aspects. Postgrad Med f 1966; 42: 153-76.

22 Laragh JH. Hormones and the pathogenesis of congestive heart failure: vasopressin, aldosterone and angiotensin II. Circulation 1962; 25: 1015-23.

23 Tagawa H, Vander AJ, Bonjour JP, Malvin RL. Inhibition of renin secretion by vasopressin in unanesthetized sodium-deprived dogs. Am F Physiol 1971; 220: 949-51.

24 Goldsmith S, Francis G, Levine TB, Cowley A, Cohn JN. Elevating plasma arginine vasopressin levels in congestive heart failure and neurohumoral response to tilt. Clin Res 1980; 28: 710A. 
25 Andersson B. Regulation of water intake. Physiol Rev 1978; 58: 582-603.

26 Fitzsimons JT, Simons BJ. The effect on drinking in the rat of intravenous infusion of angiotensin, given alone or in combination with other stimuli of thirst. $\mathcal{F}$ Physiol 1969; 203: 45-57.

27 Yamamoto K, Hasegawa T, Miyazaki M, Ueda J. Control of renin secretion in the anesthetized dog. II. Relationship between renin secretion, plasma sodium concentration and GFR in the perfused kidney. fpn $_{\text {Circ }} \mathcal{f}$ 1969; 33: 593-600.

28 Albrecht PH, Vander AJ, Turcotte JG. Effects of saline loading on the renin, erythropoietin, and blood pressure responses to canine renal allotransplantation. Circ Res 1969; 25: 99-105.

29 Brown JJ, Davies DL, Lever AF, Robertson JIS. Plasma renin concentration in human hypertension: I. Relationship between renin, sodium, and potassium. Br Med $\mathcal{J}$ 1965; ii: $144-8$.

30 Atkinson AB, Brown JJ, Dávies DL, et al. Hyponatraemic hypertensive syndrome with renal-artery occlusion corrected by captopril. Lancet 1979; ii: 606-9.

31 Coghlan JP, Blair-West JR, Denton DA, et al. Control of aldosterone secretion. F Endocrinol 1979; 81: 55P-67P.
32 Vander AJ. Direct effects of potassium on renin secretion and renal function. Am $\mathcal{F}$ Physiol 1970; 219: 455-9.

33 Shade RE, Davis JO, Johnson JA, Witty RT. Effects of renal arterial infusion of sodium and potassium on renin secretion in the dog. Circ Res 1972; 31: 719-27.

34 Ader R, Chatterjee K, Ports T, Brundage B, Hiramatsu B, Parmley W. Immediate and sustained hemodynamic and clinical improvement in chronic heart failure by an oral angiotensin-converting enzyme inhibitor. Circulation 1980; 61: 931-7.

35 Cohn JN, Mashiro I, Levine TB, Mehta J. Role of vasoconstrictor mechanisms in the control of left ventricular performance of the normal and damaged heart. Am $\mathcal{F}$ Cardiol 1979; 44: 1019-22.

36 Levine TB, Franciosa JA, Cohn JN. Acute and longterm response to an oral converting-enzyme inhibitor, Captopril, in congestve heart failure. Circulation 1980; 62: $35-41$.

Requests for reprints to Dr Jay N Cohn, University of Minnesota Hospital, Box 488, Minneapolis, Minnesota 55455, USA. 